\title{
Genç Yetişkin,Yetişkin ve Yaşlı Anadolu Erkeklerinde Burun Tiplerinin Çoklu Uyum Analizi ile İncelenmesi
}

\author{
DOI: 10.26466/opus.515221 \\ *
}

\section{Vahdet Özkoçak}

\author{
* Dr, Öğr. Üyesi Hitit Üniversitesi, Fen-Edebiyat Fakültesi, Merkez /Çorum / Türkiye \\ E-Posta: vahdetozkocak@hitit.edu.tr \\ ORCID: $\underline{0000-0002-4603-2548}$
}

\section{Öz}

Uyum Analizi (Correspondence Analysis), kategorik değişkenlerin yorumlanmasını kolaylaştıran, çapraz tablolarda (uyum tablosu, olumsallik tablosu, kontenjans tablosu, çapraz tablo, birliktelik tablosu) satır ve sütun değişkenleri arasındaki benzerlik, farklılık ve ilişkilerin yorumlanmasını kolaylaştıran ve bu değişkenlerin birlikte değişimlerini, daha az boyutlu bir uzayda grafiksel olarak gösteren bir yöntemdir. Özellikle tıp, săglık bilimleri, biyometri, ekonomi, pazarlama ve sosyal bilimler gibi kategorik verilerin analizine ihtiyaç duyulan alanlarda oldukça popüler bir yöntemdir. Uyum analizinin, çok değişkenli analiz tekniklerinden Temel Bileşenler Analizi (Principal Component Analysis), Log-Lineer (LogLinear) ve Çok Boyutlu Ölçekleme (Multi Dimensional Scaling) yöntemleriyle de benzerliği bulunmaktadır. Türkiye' de 20 yaş ve üzeri toplam 300 sağlıklı gönüllü bireyin ölçülen burun tipi gamındaki profilini ortaya koymak için 4 burun tipi belirlenmiştir. Bunlar; narrow, medium, broad, very broad. Belirlenen bu tiplerin yaş durumlarına göre uyum analizi yapılmıştır. Çoklu uyum analizi sonucunda ilgili değişkenlerin ilk iki boyutu açıklama oranı \%100 olarak bulunmuştur. İlgilenilen değişkenlerden burun tipi durumu \%83,1'lik bir oranla birinci boyutta, yaş kategorileri ile burun tipi yakınması ise $\% 16,9^{\prime}$ lik bir oranla ikinci boyutta ağırlıkl olduğu gözlemlenmiştir.

Anahtar Kelimeler: Çoklu Uyum Analizi, Homojenlik Analizi, Ağırlıklı En Küçük Kareler, Adli Bilimler, Adli Antropoloji 


\title{
Investigation of Nose Types of Young Adult, Adult and Elderly Anatolian Men With Multiple Adaptation Analysis
}

\begin{abstract}
Correspondence Analysis, which facilitates the interpretation of categorical variables, facilitates the interpretation of similarities, differences and interrelations between the row and column variables in cross tables (compliance table, contingency table, concurrency table, crosstable, correspondence table) and changes of these variables together, is a method that shows graphically in space. It is a very popular method especially in areas where categorical data such as medicine, health sciences, biometrics, economics, marketing and social sciences are needed. Compatibility analysis is also similar to the Principal Component Analysis, Log-Linear and Multi Dimensional Scaling methods. In Turkey 20 years and older 4-type nose for a total of 300 healthy volunteers to demonstrate the profile of the measured range was determined nose type. These; narrow, medium, broad, very broad. Compliance analysis was performed according to the age of these types. As a result of the multiple fit analysis, the first two dimensions of the related variables were $100 \%$. The nasal type was observed to be predominant in the first dimension with a rate of $83.1 \%$ and the nasal type with a $16.9 \%$ ratio in the second dimension.
\end{abstract}

Keywords: Multiple Correspondence Analyses, Homogeneity Analyses, Weighted Least Squares, Forensic Sciences, Forensic Anthropology 


\section{Giriş}

Yüz ölçümleri, burun, yüz tipleri ve oranları en eski medeniyetlerden günümüze kadar hep merak konusu olmuştur. Bu çalışmalara, ilk kez mağaralarda bulunan çizimlerde rastlanılmıştır ve halen günümüzde de devam etmektedir (Uzun ve Özdemir, 2014). Eski Anadolu toplumlarını ele alan araştırmalar incelendiğinde, yüz bölgesinden kraniyometri ve yumuşak dokudan antropometrik ölçümler üzerine yapılan detaylı bir çalışma olmadığ 1 da görülmüştür. Tarihsel zaman sürecinde populasyonlar arasındaki morfolojik ve biyolojik ilişkilerin belirlenmesi, kültürel ilişkileri araştırmak kadar önemli yer tutar. Bundan dolayı, yüz ölçümleri sadece Adli Antropoloji açısından değil Fiziki Antropoloji ve sağlık alanında plastik rekonstrüktif, ortodontik maxillo-fasyal cerrahi gibi diğer disiplinler açısindan da oldukça önemlidir. (Özdemir ve Özkoçak, 2017).

Organizmalar için şekil, fenotipin en göze çarpan özelliği olup genotip ve çevre arasındaki bağlantıyı sağladığından, bilimsel çalışmalar açısından yüzyıllardır dikkat çekici bir özellik olarak karşımıza çıkar. Günümüzde birçok canlıda şekil varyasyonu, uzuvlar arasındaki uzaklık ölçüleri ve açı değerleri kullanılarak geleneksel morfometrik yöntemler ile ortaya konulmaya çalışılmıştır. Şekil varyasyonunu ortaya çıkarmak için bu yaklaşım, son zamanlarda yerini "Geometrik Morfometri" metoduna b1rakmış olup, çok çeşitli biyolojik çalışmalarda da bu yöntem kullanılmaya başlanmıştır. "Geometrik Morfometri" metodu, matematiksel bir temele dayanır. Şekil analizi ile varyasyonun ortaya çıkardığı çeşitliliği ve morfolojik dönüşümü ortaya koymaktadır (Özkoçak ve Görgün, 2018).

Geometrik morfometri yaklaşımları, Antropometrik ölçümlerin direkt olmayan yani indirekt olan metotlarını kullanır. Bireylerin vücudundan, küçük-büyük çap pergeli ve antropometri tahtası benzeri antropometrik aletlerle alınamayan, ancak antropometrik ölçümlere olanak sağlayan verilerin başında, bireylerin genel veya spesifik alan fotoğrafları gelmektedir. Bu resimlerin analizinde, dolaylı yani indirekt Antropometri ölçümlerinde kullanıldığı için, Geometrik Morfometriyi de Antropometrik ölçümlerden faydalanan yeni bir disiplin olarak görebiliriz (Özkoçak ve Görgün, 2018). 
Adli makamlarda, suçlunun analizi yani kimliklendirme için yüz tanıma oldukça önemlidir. Bazı adli durumlarda ve özellikle görüntü inceleme çalışmalarında Geometrik Morfometri metodu önemini daha da artırmaktadır. Kalabalık içerisinde yer alan bir kişinin görüntüsünden veri tabanında yer alan bir çizim veya görüntü ile eşleştirilmesi sağlanarak kimliklendirme yapılabilir. Edimsel yüz imgeleri ile daha önce sorguya alınmış ya da adli olaya karışmış kişinin görüntüleri hızlı bir şekilde karşılaştırılabilinir. Var olan veri tabanından elde edilen görüntüler kullanılacağ i için, bu karşılaştırmanın maliyeti neredeyse yoktur. Sadece tarama için vakit gereklidir. Şüpheli gözaltında iken, elde edilen verilerle kıyaslama yapılarak kişinin suçlu olup olmadığı hakkında kesin bir bilgiye sahip olmamızı sağlar. Kimliklendirmede kullanılan diğer bir yardımcı metod olan yeniden yüzlendirme ise zaman alan ve kişisel faktörlere bağlı olarak hata payı yüksek, maliyeti daha az ama güvenilirliği daha düşük olan bir yöntemdir. Bu nedenle dijital verilerden ve mevcut veri tabanlarından yüz tanıma, Adli Bilimciler ve Adli Antropologlar tarafından sıklıkla kullanılan yöntemlerin başında gelmektedir (Özdemir ve Özkoçak, 2017, Çetli ve Özkoçak, 2018).

Kısaca yüz bölgesinin kimliklendirme açısından önemi, Adli Bilimlerde yerini almıştır. Çünkü birini tanımanın en kolay yolu yüzüne bakmaktır. CCTV kameralardan elde edilen görüntülerden veya fotografik verilerden, yürüyüş şekli ve bacak arası açıklığı son dönemlerde kimliklendirmede önemli bir yere sahip olsa da, arkadaş çevresi ve yakın aile bireyleri tarafından kişileri tanımada yüz bölgesi her zaman bir adım önde olacaktır. Öyle ki bir görgü tanığının, fotoğraf veya video kaydından suçluları tespit etmesinde, yüz bölgesi hayati öneme sahiptir (Kleinberg, 2008). Bu çalışmanın amacı, Anadolu erkeklerindeki genç yetişkin, yetişkin ve yaşlılarda yüz ve burun tiplerine ve yüzdeki oranlara göre, yaşla ilişkili değişiklikleri tanımlamak ve karşılaştırmaktır (Özdemir ve Özkoçak, 2017, Özkoçak ve Özdemir, 2018).

Türkiye' de Ankara ve çevresinde yaşayan bireylerden alınan ölçülerle Burun Tipi ile yaş aralığına ait kategoriler Tablo 1'de belirlenmiştir. Belirlenen bu fenotiplerin hangi sıklıkla olduğu durumlarına göre uyum analizi yapılmıştır. 
Tablo 1. Burun Tipi ve Yaş Kategorileri

\begin{tabular}{llll}
\hline Burun Tipleri & $20-39$ & $40-59$ & $60+$ \\
\hline Dar & 22 & 14 & 17 \\
Orta & 59 & 48 & 48 \\
Geniş & 19 & 35 & 29 \\
Çok geniş & & 3 & 6 \\
\hline
\end{tabular}

Veriler 2015 yılı Anadolu erkeklerinde burun, yüz tipleri ve oranlarının yaşa bağlı değişimleri araştırmasında burun tipi ölçümlerinden derlenmiştir. Verilerin değerlendirilmesinde SPPS 25 (IBM Corp. Released 2017. IBM SPSS Statistics for Windows, Version 25.0. Armonk, NY: IBM Corp.) istatistik paket programı kullanılmıştır.

\section{Yöntem}

Çalışma; Ankara merkez ve ilçelerinde yaşayan ve rastgele örnekleme metoduyla seçilen 300 sağlıklı gönüllü bireyden (100'ü 20-40, 100'ü 40-60 ve 100 'üde 60 yaş ve üstü) oluşmaktadır. Katılımclar, kranyofasiyal bölgesinde belirgin bir asimetrik görünümü olmayan, burun gelişiminde herhangi bir değişikliğe neden olabilecek hastalık, konjenital anomali, travma veya cerrahi öyküsü olmayan tamamen sağlıklı bireylerden seçilmiştir. Kranyofasiyal bölgesinde travma veya cerrahi operasyon geçirmiş bireyler çalışmaya dahil edilmemiştir. Çalışmada her birey bir sandalyede, başı dik, oturur pozisyonda, gözleri tam karşıya bakacak, pupillaları santral noktada fikse olacak şekilde "Frankfurt Horizontal Düzleminde" aynı fotoğraf makinesinde 1,5 metre mesafeden olacak şekilde fotoğrafları çekilmiştir. Çalışmamızda indirekt antropometrik ölçüm teknikleri kullanılarak, baş ve yüz bölgesinden, tek bir araştırmacı tarafından, literatürde belirlenen noktalardan ölçümler alınarak, Image J programıla çekilen fotoğraflar üzerinden değerlendirilmişlerdir.

$\mathrm{Bu}$ çalışmada aşağıdaki parametreler ölçüldü ve kaydedildi: burun genişliği; alare-alare (al-al) ve toplam burun uzunluğu; nasion-subnasale (n-sn).

Burun İndeksi = burun genişliği (al-al) × 100 / toplam burun uzunluğu (n-sn) Endekse göre, burun yedi tipe ayrılır (Olivier sınıflandırması). 
Ayrıca: aşırı dar burun (X-39.99), çok dar burun (40.00-54.99), dar burun (55.00-69.99), orta burun (70.00) -84.99), geniş burun (85.00-99.99), çok geniş burun (100.00-114.99) ve aşırı geniş burun (115.00-X) .14

Çoklu uyum analizi, verilerin indikatör matrisinin analiz edilmesiyle basit uyum analizinin $Q$ kategorik değişken durumuna genelleştirilmişidir. q. Değişkenin jq kategorisi olduğu ve kategorilerin toplamının $J=\sum J_{q}$ olduğu varsayılsın. $\mathrm{N}$ birim olduğunda $\mathrm{Z}$ indikatör matrisi, sıfır ve birlerden oluşan nxJ boyutlu bir matris olur. $Z$ indikatör matrisinin analizinde toplam varyasyon, bir kontenjans tablosu gibi $\mathrm{Z}$ üzerinden hesaplanan ve $\chi_{z}^{2}=n(J-Q)$ şeklinde tanımlanan ki-kare istatistiği olmaktadır (Nishisato, 1980;Cangür ve ark. 2005).

$\mathrm{Z}$ indikatör matrisi $\mathrm{Z} \equiv\left[Z_{1} \ldots . . Z_{Q}\right]$ şeklinde ifade edilmektedir. $Z_{q}\left(n x J_{q}\right), J_{q}$ kategorileriyle q. Kategorik değişkeni göstermektedir. B Burt matrisi simetrik olduğundan $\mathrm{Z}$ indikatör matrisinin uyum analizindeki optimal sütun parametreleri, B Burt matrisinin analizindeki ya satır ya da sütun parametreleriyle benzer olduğu gösterilebilir. B matrisinin temel inertiaları ( $\mu_{k}^{2}$ bileşenleri), $\mathrm{Z}$ indikatör matrisindekilerin kareleridir. Böylece B'nin bulunmasıyla, Z'nin çoklu uyum analizindeki sütunları (kategoriler) için yeniden çözüm yapılabilir. Z indikatör matrisi, verilerde yer alan çok yönlü bilgiyi kapsamasına rağmen çoklu uyum analizinin, sadece iki yönlü bilgiyi analiz ettiği açıkça görülmektedir. Bunun sonucu olarak; çoklu uyum analizinin, Burt matrisin ağırlıklı en küçük kareler yaklaşımı olduğu söylenebilir. Ki-kare istatistiği, bir kontenjans tablosu gibi B için tekrar hesaplanabilir. Basitleştirilmiş şekli aşağıdaki gibi

$$
\chi_{B}^{2}=\sum \sum_{q \neq s} \chi_{q s}^{2}+n(J-Q)
$$

Yazılabilir. Burada $\chi_{q s}^{2}$, diyagonal dişındaki elemanlardan oluşan $N_{q s}^{2}=Z_{q}^{\prime} Z_{s}$ alt tablo için ki-kare istatistiğidir. Toplam varyasyonun ölçüsü $\sum \sum_{q \neq s} \chi_{q s}^{2}$ dir Greenacre, 1981-88; Suner ve Çelikoğlu, 2008).

Bir B Burt matrisi verildiğinde çoklu uyum analizi, 


$$
b^{-1 t r}\left\{D_{r}^{-1}(B-H) D_{r}^{-1}(B-H)^{\prime}\right\}
$$

eşitliğini minimize eden daha düşük ranklı $\mathrm{H}$ matrisiyle, B'nin ağırlıklı en küçük kareler yaklaşımı olarak tanımlanabilir. Bu B Burt matrisinin uyum analizidir. Burada b, B matrisinin genel toplamıdır. Dr ise B matrisi simetrik olduğundan satır ve sütun kategori oranlarının diyagonal matrisidir. B Burt matrisinin her bir $\mathrm{N}_{\mathrm{qs}}$ alt tablosu, çapraz tablolar haline getirilmiş olan $\mathrm{n}$ birimin toplam sayısına eşit olduğundan, $b=N Q^{2}$ şeklinde ifade edilebilir. q değişkeni için $\mathrm{J}_{\mathrm{q}}$ kategori oranlarının vektörü $\mathrm{r}_{\mathrm{q}}$ ile gösterilmektedir (1' $\mathrm{r}_{\mathrm{q}}=1$ ). Aynı zamanda bu herhangi bir s için $\mathrm{N}$ qs 'nin satır kategori oranlarının bir setidir.

$\mathrm{q}$ r 'nun elemanlarından forme edilen $\mathrm{J}_{\mathrm{q}} \times \mathrm{J}_{\mathrm{q}}$ boyutlu diyagonal matris $D_{q}$ ile gösterilmektedir. Bu doğrultuda eşitlik

$$
\begin{aligned}
& n^{-1} \operatorname{tr}\left\{D_{r}^{-1}(B-H) D_{r}^{-1}(B-H)^{\prime}\right\}= \\
& n^{-1} \sum_{q=1}^{Q} \sum_{s=1}^{Q}\left\{D_{q}^{-1}\left(N_{q s}-H_{q s}\right) D_{s}^{-1}\left(N_{q s}-H_{q s}\right)^{\prime}\right\}
\end{aligned}
$$

şeklinde yeniden yazılabilir. Burada $\mathrm{H}, \mathrm{H}_{\mathrm{qs}}$ 'nin süpermatrisidir (Benzécri, 1972; Greenacre, 1984; Lebart, 1976 Lebart ve ark, 1984; Hiil ve Gauch, 1980; Gifi, 1990).

$$
\left\|N_{q s}-H_{q s}\right\|_{q s}^{2}=t r
$$

Bu durumda

$$
\left\{D_{q}^{-1}\left(N_{q s}-H_{q s}\right) D_{s}^{-1}\left(N_{q s}-H_{q s}\right)^{\prime}\right\} \text { olduğundan eşitlik (3) aşă̆ıdaki }
$$
gibi daha basit formda yazılabilir.

$$
\left.n^{-1} \sum_{q} \sum_{s} \| N_{q s}-H_{q s}\right)^{\prime} \|_{q s}^{2}
$$


Bu metotla minimize edilen fonksiyon, B'nin diyagonal elemanlarının üst kısmındaki elemanlarının oluşturduğu alt tabloya karşılık gelen $\frac{1}{2} Q(Q-1)$ teriminin toplamı olan

$$
\left.n^{-1} \sum \sum_{q<s} \| N_{q s}-H_{q s}\right)^{\prime} \|_{q s}^{2}
$$

dir. Eşitlik (3)'ün minimizasyonu, Healy \& Goldstein (1976) tarafından tanımlanan uyuşmazlık fonksiyonunun minimizasyonuna ve Nishisato (1980) tarafından belirlenen iç tutarlılık kriterine eşittir (Greenacre, 1984; Tekindal ve ark., 2016).

\section{Bulgular}

Tablo 2. Başlangıç matrisi analiz sonuçlan

\begin{tabular}{|c|c|c|c|c|c|c|c|c|}
\hline \multirow[b]{2}{*}{ Boyut } & \multirow[b]{2}{*}{ Değer } & \multirow[b]{2}{*}{ Inertia } & \multirow[b]{2}{*}{$\chi^{2}$} & \multirow[b]{2}{*}{$p$} & \multicolumn{2}{|c|}{ Inertia Oranı } & \multicolumn{2}{|c|}{ Güven Değeri } \\
\hline & & & & & Değer & $\begin{array}{l}\text { Kümül- } \\
\text { atif }\end{array}$ & $\begin{array}{l}\text { Standart } \\
\text { Sapma }\end{array}$ & $\mathrm{r}$ \\
\hline 1 & 198 & ,039 & & & 831 & ,831 & ,044 & ,073 \\
\hline 2 & ,089 & ,008 & & & , 169 & 1,000 & ,064 & \\
\hline Toplam & &, 047 & 14,133 & ,028 & 1,000 & 1,000 & & \\
\hline
\end{tabular}

Başlangıç matrisinin analiz sonuçları ise Tablo 2' de verilmiştir. Başlangıç matrisinin analizi sonucunda, Burt matrisinin rank 1 kadar boyut elde edilmiştir. Tablo 2'de inertia sütununda yer alan değerler, değişkenlerin kategorileri için var olan değişimin ortalama ölçüsü olarak değerlendirilen toplam değişim (inertia) içerisinde, her bir boyuta düşen değişimin miktarlarını göstermektedir. Bu değerler incelendiğinde, her bir boyutun katkısının yaklaşık olarak bir birine yakın olduğu görülür. Her bir boyutun toplam değişimi açıklamadaki payları (yüzde miktarları) ise her boyuta ait olan inertia değerinin toplam inertia değerine oranlanması ile bulunmuştur. Dolayısıyla en yüksek açılama oranı \%83,1 ile birinci boyuta aittir. Daha sonra \%16,9 ile ikinci boyut gelmektedir. Bu iki boyut toplamda \%100 açılama oranına sahiptir. 
Her ne kadar bu değişkenlere ait seviyeler arasındaki ilişkiyi iki boyutlu uzayda göstermek, toplam değişimi açıklayabilme bakımından yeterli değ il ise de, sonuçların yorumlanmasını gösterebilmek için sadece iki boyut dikkate alınmış ve bu boyutların seviyeleri ile olan korelasyon katsayıları, her bir seviyenin boyuta olan katkısı ve iki boyutlu uzaydaki koordinatı Tablo 3'de verilmiştir.

Tablo 3. Değişkenlere ait Kategorilerin Boyutlara Göre Merkezi Koordinatları

\begin{tabular}{|c|c|c|c|c|c|c|c|c|c|}
\hline \multirow{3}{*}{$\begin{array}{l}\text { Burun } \\
\text { tipi }\end{array}$} & \multirow{3}{*}{ Kütle } & \multicolumn{2}{|c|}{ Boyut Puanı } & \multirow{3}{*}{ Inertia } & & & & & \\
\hline & & \multirow{2}{*}{1} & \multirow{2}{*}{2} & & \multicolumn{2}{|c|}{$\begin{array}{c}\text { Boyuttaki Inertia } \\
\text { Oranı }\end{array}$} & \multicolumn{3}{|c|}{$\begin{array}{c}\text { Boyuttaki Inertia Nok } \\
\text { taları }\end{array}$} \\
\hline & & & & & 1 & 2 & 1 & 2 & $\begin{array}{l}\text { Top- } \\
\text { lam }\end{array}$ \\
\hline Dar & ,177 &,- 384 &,- 253 & ,006 & ,132 & ,126 & 837 & 163 & 1,000 \\
\hline Orta & ,517 &,- 226 &,- 012 & ,005 & ,133 & ,001 & ,999 & ,001 & 1,000 \\
\hline Geniş & ,277 & ,491 & ,322 & 016 & 637 & 322 & 837 & 163 & 1,000 \\
\hline $\begin{array}{l}\text { Çok } \\
\text { geniş }\end{array}$ & ,030 & 1,622 & $-1,281$ & ,020 & ,099 & ,551 & 780 & ,220 & 1,000 \\
\hline Toplam & 1,000 & & & ,047 & 1,000 & 1,000 & & & \\
\hline
\end{tabular}

Tablo 3 incelendiğinde 1 . Boyuta en çok katkı veren burun tipi "Broad"'dır. Buna rağmen birlikte incelendiğinde "Narrow" ve "very Broad" tiplerinin 1. ve 2. Boyuta birlikte hareket etme durumunu söyleyebiliriz. Tablo 3'de gösterilen sayısal değerler bir diyagramda gösterilmek istendiğinde; uyum analizi diyagramı Şekil 1'de gösterildiği gibi olacaktır. Yaş kategorileri ile benzer burun tipi kategorilerini birliktelikleri Şekil 1'de görüldüğü üzere 20-39 yaş aralığı genelde Medium ve Narrow tipindeyken, 40-59 yaş aralığı Broad tipindendir. 60+ yaş gurubu herhangi bir sınıfa yakınlık sağlamamıştır. 


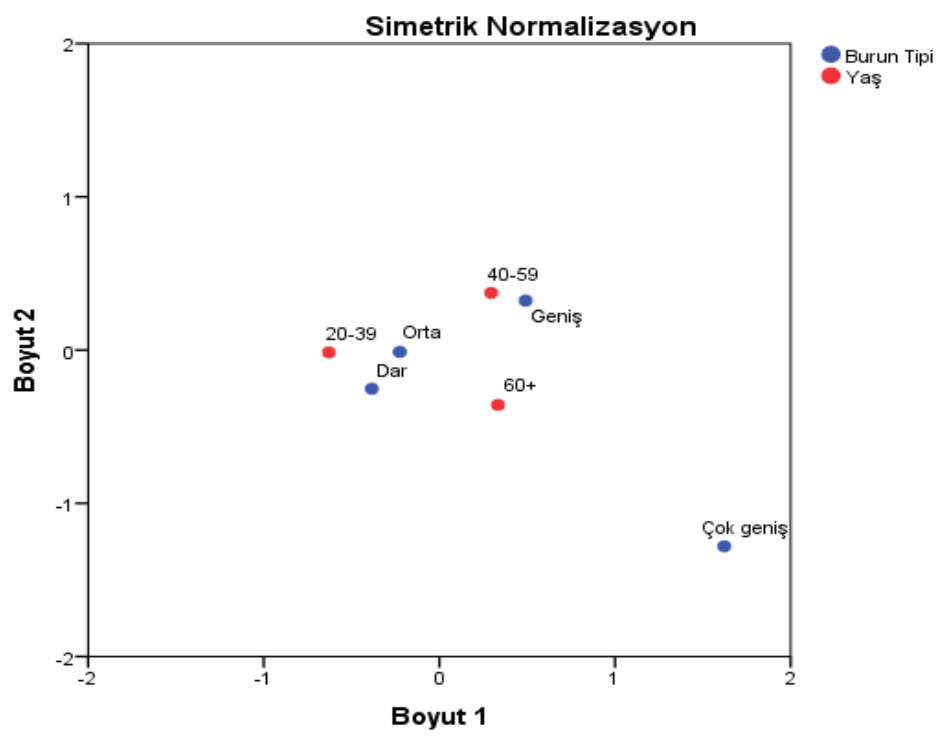

Şekil 1. Çoklu Uyum Analiz Grafiği

\section{Sonuç}

Veri indirgeme ve artık analizlerinden biri olarak, iki ya da daha fazla boyutlu grafik ile kategorik değişkenler hakkında bilgi elde edilebildiğinden, ayrıca satır profillerindeki homojenlik eksikliği ya da çapraz tablonun satır ve sütunları arasındaki bağımlılığı (ya da etkileşimi) daha düşük boyutta açıklama imkânı sağladığından uyum analizi tercih edilmektedir (Higgs, 1990).

Bu çalışma ve yapılması olası diğer çalışmalarda hem görüntü analizi hem de istatistik programlarının ve teknolojilerinin sağladığ adli bilimlerde önemli bir ivme kazanılacağı şüphesizdir. Özellikle görüntü analizi ile suçlu tespiti ve kriminal olayların aydınlatılması son zamanlarda Adli makamların sıklıkla kullandığı yöntemlerdendir. Yapılan bu çalışma ile kullanılan yeni metot ve yöntemlerin Adli Antropolojiden Adli Bilimlere kadar etkisini görebilmekteyiz. 


\title{
EXTENDED ABSTRACT
}

\section{Investigation of Nose Types of Young Adult, Adult and Elderly Anatolian Men With Multiple Adaptation Analysis}

\author{
Vahdet Özkoçak
}

Hitit University

Facial measurements, nose, face types and rates have always been the subject of curiosity from the oldest civilizations to the present day. These studies were found for the first time in the cave drawings and still continue today. For organisms, the shape is the most prominent feature of the phenotype and, since it provides the connection between the genotype and the environment, it has been a remarkable feature for scientific studies for centuries. Nowadays, in many living things, shape variation, distance between the limbs and angle values are tried to be revealed by using traditional morphometric methods. This approach, in order to reveal the variation of shape, has recently been replaced by the Geometric Morphometry method and this method has been used in a wide variety of biological studies.

The geometric morphometry method is based on a mathematical basis. It shows the diversity and morphological transformation of variation by shape analysis. Geometric morphometry approaches use methods which are not direct, ie indirect, of anthropometric measurements. At the beginning of the data which can not be taken from individuals' body with smalllarge calipers and anthropometric instruments like anthropometry, but which allows for anthropometric measurements, general or specific area photographs of the individuals come. As these images are used indirectly for indirect antropometry measurements, we can see Geometric Morphometry as a new discipline benefiting from Anthropometric measurements. Briefly, the importance of facial region in terms of identification has taken its place in forensic sciences. Because one of the easiest ways to know someone is to look at someone's face. Although it has an important 
place in identifying walking and leg openness recently from CCTV cameras or photographic data, the facial region will always be one step ahead in recognizing people by friends and close family members. Thus, an eyewitness, photo or video recording of the face area is vital in the detection of criminals (Kleinberg, 2008). The aim of this study was to identify and compare age-related changes in young adults, adults and the elderly in Anatolian males according to the facial and nose types and facial features. Data were compiled from nasal type measurements in the study of agerelated changes of nose, facial types and rates in Anatolian men in 2015. In order to evaluate the data, the SPPS 25 (IBM Corp. Released 2017. IBM SPSS Statistics for Windows, Version 25.0. Armonk, NY: IBM Corp.) statistical package was used. $T$

he multiple fit analysis is generalizaition of the categorical variable state $Q$ of simple conformity analysis by analyzing the indicator matrix of the data. Assume that the q variable is the category jq and that there is a sum of categories. When $\mathrm{N}$ is the unit, the $\mathrm{Z}$ indicator matrix is a zero and one $\mathrm{nxJ}$ matrix. In the analysis of the $Z$-indicator matrix, the total variation is the chi-square statistic, which is defined as and calculated over $Z$, such as a contingency table. $Z$ indicator matrix is expressed as $Z$. $q$ with categories. It shows the categorical variable. Because the $B$ Burt matrix is symmetrical, the optimal column parameters in the fit analysis of the $\mathrm{Z}$ indicator matrix can be shown to be similar to either the row or column parameters in the $B$ Burt matrix analysis. The basic inertia (s) of matrix $B$ are the squares of those in the $Z$ indicator matrix. Thus, with the discovery of $\mathrm{B}, \mathrm{Z}$ can be solved again for columns (categories) in the multiple fit analysis. Although the $\mathrm{Z}$ indicator matrix covers the multidimensional information contained in the data, it is clear that multiple fit analysis analyzes only two-way information. As a result; it can be said that the multiple fit analysis is the smallest squares approach of Burt matrix. The chi-square statistic can be recalculated as B for a contingency table. Simplified shape can be given as follows:

$$
\chi_{B}^{2}=\sum \sum_{q \neq s} \chi_{q s}^{2}+n(J-Q)
$$


Here $\chi_{q s}^{2}$ is the chi-square statistic for the $N_{q s}^{2}=Z_{q}^{\prime} Z_{s}$ sub-table consisting of elements other than diagonal. Measure is $\sum \sum_{q \neq s} \chi_{q s}^{2}$. The "wide" nose type is the one that contributes most to the first dimension. However, when examined together, we can say that "narrow" hareket and "very wide" types of noses act together in the first and second dimensions. As a result of the analysis of the starting matrix, the size of the Burt matrix was obtained. The values in the Inertia column indicate the amount of change in each dimension in the total change (inertia), which is considered the mean measure of the change for the categories of variables. When these values are examined, it is seen that the contribution of each dimension is close to approximately one. The total change of each dimension was found by dividing the shares (percentages) in the description by the ratio of the inertia value of each dimension to the total inertia value. Therefore, the highest explanation rate is $83.1 \%$. Then comes the second dimension with $16.9 \%$. These two dimensions have a $100 \%$ explanation rate in total. Although the relation between the levels of these variables in two-dimensional space is not sufficient to explain the total change, only two dimensions are taken into account to show the interpretation of the results and the correlation coefficients with the levels of these dimensions, the contribution of each level to the dimension and the two-dimensional The coordinate in space is given in Table 3. Age categories and similar nosocomial categories are in the 20-39 age range, generally in the Medium and Narrow types, and in the 40-59 age range. The 60+ age group did not provide any proximity to any class. In this study and other possible studies, there will be no significant acceleration in forensic sciences with both image analysis and the opportunities provided by statistical programs and technologies. Especially for the detection of criminals and the detection of criminal events by image analysis, the most common methods used by the judicial authorities in recent times. With this study, we can see the effect of new methods used from forensic anthropology to forensic sciences. 


\section{Kaynakça / References}

Benzécri, J.-P. ve ark. (1972). L'Analyse des Données, tome 1: La Taxinomie, tome 2: l'Analyse des correspondances, Dunod, Paris.

Cangür Ş., Sığırlı D., Ediz B., Ercan İ., Kan İ. (2005). Türkiye'de özürlü grupların yapısının çoklu uyum analizi ile incelenmesi. Uludă̆g Üniversitesi Tıp Fakültesi Dergisi 31 (3) 153-157.

Cetli, E., Özkoçak, V. (2018)," Use Of Recorded Personal Data In Forensic Sciences", Avrasya Sanat Ve Medeniyet Dergisi, S.10, s.1-12.

Gifi, A. (1990). Nonlinear multivariate analysis. New York, John Wiley\&Sons.

Greenacre, M. J. (1981). Practical correspondence analysis. Interpreting Multivariate Data. (Editor, V. Barnett), John Wiley \& Sons. Ltd., Chichester: U.K., s.119-146.

Greenacre, M. J. (1984). Theory and applications of correspondence analysis. London: Academic Press. Inc.

Greenacre M.J. (1988). Correspondence analysis of multivariate categorical data by weighted least-squares. Biometrika, 75, 457-67.

Higgs N.T. (1990). Practical and innovative uses of correspondence analysis. The Statistician, 40, 183-94.

Lebart, L. (1976). The significancy of eigenvalues issued from correspondence analysis. Proc. Comp. Statist, Vienna: Physica Verlag, 38-45.

Lebart, L., Morineau A. and Warwick, K.M. (1984). Multivariate descriptive statistical analysis. New York: J. Wiley.

M. O. Hill ve H. G. Gauch Jr. (1980). Detrended correspondence analysis: An improved ordination technique. Vegetatio 42(1/3), 47-58

Nishisato, S. (1980). Analysis of categorical data: Dual scaling and its applications. Toronto: University of Toronto Press

Özdemir, F. ve Özkoçak, V. (2017). Anadolu erkeklerinde burun, yüz tipleri ve oranlarının yaşa bağlı değişimleri. The Journal of International Lingual, Social and Educational Sciences, 3(2), 135-142.

Özkoçak, V ve Görgün, A. (2018). Estimation of anatomical points (landmarks) of right ear over 60 years old anatolian men by artificial neural networks. Contemporary Debates in Social Sciences. First Edition, September 2018 IJOPEC Publication No: 2018/31, 21-36. 
Özkoçak, V. ve Özdemir, F. (2018). Age-related changes in the external noses of the Anatolian men. Part of Springer Nature and International Society of Aesthetic Plastic Surgery.

Suner A., ve Çelikoğlu C. C. (2008). Uygunluk analizinin benzer çok değişkenli analiz yöntemleri ile karşılaştırılması. İstatistikçiler Dergisi, 1, 9-15.

Tekindal M. A., Uysal U.C, Dolgun, M.O. (2016). Examining public purchases in themedical field with multiple correspondence analysis. Biomedical Research; Special Issue(Special Section: Health Science and Bio Convergence Technology), 366-S370

Uzun, A. ve Özdemir, F. (2014). Morphometric analysis of nasal shapes and angles in young adults. Braz J Otorhinolaryngol, 80, 397-402.

\section{Kaynakça Bilgisi / Citation Information}

Özkoçak, V. (2019). Genç yetişkin,yetişkin ve yaşlı Anadolu erkeklerinde burun tiplerinin çoklu uyum analizi ile incelenmesi. OPUSUluslararası Toplum Araştırmaları Dergisi , 10(17), 638-652. DOI: 10.26466/opus.515221 